\title{
Gastrointestinal parasites of two populations of Arctic foxes (Vulpes lagopus) from north-east Greenland
}

\author{
Pipaluk Nynne Skamris Andreassen, ${ }^{\mathrm{a}}$ Niels Martin Schmidt (10) ${ }^{\mathrm{b}}$ Christian Moliin Outzen Kapel (1) \\ Martin Ulrich Christensen, ${ }^{\mathrm{b}}$ Benoît Sittler, ${ }^{\mathrm{d}, \mathrm{e}}$ Olivier Gilg (ef $^{\text {ef }}$ Heidi Larsen Enemark ${ }^{\mathrm{a}}$ \\ \& Mohammad Nafi Solaiman Al-Sabi (i)
}

\begin{abstract}
aSection for Bacteriology, Pathology and Parasitology, Technical University of Denmark, Frederiksberg C, Denmark; ${ }^{b}$ Department of Bioscience, Arctic Research Centre, Aarhus University, Roskilde, Denmark; 'Department of Plants and the Environment, Faculty of Sciences, University of Copenhagen, Frederiksberg C, Denmark; Institute of Applied Conservation, University of Freiburg, Freiburg,

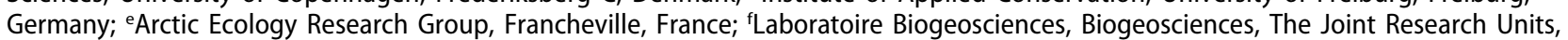
The National Centre for Scientific Research, University of Burgundy, Dijon, France
\end{abstract}

\begin{abstract}
Parasitological examination of 275 faecal samples from Arctic foxes (Vulpes lagopus) collected at Zackenberg Valley and Karupelv Valley in north-east Greenland from 2006 to 2008 was conducted using sieving and microscopy. Overall, 125 (45.5\%) samples contained parasite eggs of Taenia crassiceps, Taenia serialis, Toxascaris leonina, Eucoleus boehmi, Physalopteridae and Ancylostomatidae, and Strongyloides-like larvae. As long-term ecological studies are conducted at both sampling locations, the present findings constitute a baseline data set for further parasitological monitoring.
\end{abstract}

\section{KEYWORDS}

Arctic parasites; coprological examination; Taenia; Toxascaris leonina; Eucoleus boehmi; faecal analysis
Climate changes in the Arctic, including Greenland, result in rapid environmental and ecosystems changes (Post et al. 2009; Gilg et al. 2012), which in turn may affect parasite transmission (Davidson et al. 2011). As a key predator in the Arctic (Ehrich et al. 2015), the Arctic fox (Vulpes lagopus) is one of the species chosen by the International Union for Conservation of Nature to be monitored as part of efforts to understand the consequences of climate changes on the tundra ecosystem (IUCN 2009). Since changes in the dynamics of parasitism in the Arctic may have direct influence on wildlife populations (Davidson et al. 2011), baseline knowledge of parasite diversity in this key predator may contribute to mapping effects of climate changes on population dynamics in Greenland.

\section{Materials and methods}

Two High-Arctic tundra areas in north-east Greenland were sampled in this study: Zackenberg Valley $\left(74^{\circ} 28^{\prime} \mathrm{N} ; 20^{\circ} 34^{\prime} \mathrm{W}\right)$ and $250 \mathrm{~km}$ south of Zackenberg Valley, the Karupelv Valley located on Traill Island $\left(72^{\circ} 30^{\prime} \mathrm{N} ; 24^{\circ} 00^{\prime} \mathrm{W}\right)$. The terrestrial vertebrate community is the same in both areas, with cyclic collared lemming (Dicrostonyx groenlandicus) being the only rodent species and main prey of four predator species - Arctic fox, stoat (Mustela erminea), snowy owl (Bubo scandiacus) and long-tailed skua (Stercorarius longicaudus) - while a few other bird and mammal species, including carcasses of muskox (Ovibos moschatus), are also used as alternate food by Arctic foxes in low lemming years (Gilg et al. 2006; Schmidt et al. 2012; Schmidt et al. 2015). Research on the relationship between lemmings and their predators, including the Arctic fox, has been conducted in Zackenberg Valley since 1995 (Schmidt et al. 2008; Schmidt et al. 2012) and in Karupelv Valley since 1988 (Sittler 1995; Gilg et al. 2003).

Faeces were sampled in May-August in Karupelv Valley in 2006 and 2007 and in Zackenberg Valley from 2006 to 2008. During the sampling periods, mean temperatures in summer months (MayAugust) generally ranged from 1 to $8.7^{\circ} \mathrm{C}$ (Hansen et al. 2008). Usually, there is snow cover from September to June/July (Gilg et al. 2009). In Zackenberg Valley, all old faeces were removed from the dens during the first visit in each year to ensure that only new scats were collected. The 224 faeces samples were primarily collected from the ground near four different Arctic fox dens. The remaining scats were collected in the surroundings at irregular intervals during other fieldwork. In Karupelv Valley, most of the 51 faeces samples were fresh or recently deposited. Most faeces were sampled from the ground in or near two different Arctic fox dens or near the researchers' campsite, while 10 
samples were found in or near the winter nests of collared lemmings. Since only relatively large faeces were collected, the faeces analysed in our study likely originated from a minimum of 10 different adult foxes.

Faecal samples were stored in individual tubes marked with collection site and date, and were kept in $70 \%$ ethanol at $-20^{\circ} \mathrm{C}$ (Mathis et al. 1996), except for 18 faecal samples from Karupelv Valley collected in 2007, which were stored in a DNA-preservative (PSP • Spin Stool DNA Plus Kit, Stratec Biomedical AG). A total of 275 faecal samples were analysed. Parasitic stages were isolated using a sieving procedure modified from Mathis et al. (1996) and Al-Sabi et al. (2010). Briefly, the samples were shaken to resuspend precipitated eggs and the fluid was poured through a layer of gauze and through a sieve (20$22 \mu \mathrm{m})$. Two grams of the faecal sample were homogenized with $36 \mathrm{~mL}$ deionized water and poured through gauze into a collection cup. Then the filtered material was transferred to four $10 \mathrm{~mL}$ tubes and centrifuged at $178 \mathrm{~g}$ for $10 \mathrm{~min}$. Supernatants were removed and flotation fluid (sugar [D-(+)-glucose monohydrate]-salt [sodium chloride], sp. gr. 1.2) was added to each tube followed by centrifugation at $53 \mathrm{~g}$ for $1 \mathrm{~min}$. Subsequently, the supernatants were poured through the $20-22 \mu \mathrm{m}$ sieve used earlier and washed three or four times with deionized water. Retained particles were backwashed into a $3.5 \mathrm{~cm}$ Petri dish for examination using an inverted microscope (Leica Leitz DM IL) at 100× and 200× magnification. For observation at higher magnification, parasite eggs or larvae were transferred to a glass slide using a glass pipette, examined by light microscopy (Leica DMR) at $400 \times$ and $630 \times$ magnifications, and identified by morphology (Zajac et al. 2012). Twenty sediments containing taeniid eggs (range: 7-73 eggs) were transferred to $2 \mathrm{~mL}$ tubes and centrifuged at $6000 \mathrm{~g}$ for $3 \mathrm{~min}$, and stored at $-20^{\circ}$ $\mathrm{C}$ until subsequent molecular typing.

For molecular typing of taeniid eggs, the sediments were homogenized using a specialized bead-beating apparatus (FastPrep ${ }^{\circ}$-24, MP Biomedicals Inc.) utilizing $0.5 \mathrm{~mm}$ magnetic beads beaten six times for $60 \mathrm{~s}$ at intervals each with $0.5 \mathrm{~m} \mathrm{~s}^{-1}$ increments and DNA was extracted using a commercial kit (QIAmp DNA Stool Mini Kit', Qiagen $\mathrm{GmbH}$ ). The mitochondrial ssu rRNA gene was amplified using the Cest3-Cest5 primers as previously described (Trachsel et al. 2007). Sequencing of the polymerase chain reaction amplicons (267 base pair) was done in both directions using a commercial kit (ABI Prism Big Dye Terminator v 3.1 Sequencing Kit, Applied Biosystems). Consensus sequences were established using MEGA6 (Tamura et al. 2013) and were compared to available sequences in GenBank after BLASTn analysis.

\section{Results and discussion}

Parasite eggs/larvae were recovered from 125 of 275 (45.5\%) faecal samples (Table 1). Molecular typing of taeniid eggs was successful for seven samples, out of 20 samples that had taeniid eggs in, and the resulting sequences are available in GenBank under accession numbers KP965908-KP965913. One sample from Zackenberg Valley (2007) was typed as Taenia serialis (not reported previously in Arctic fox), while six samples from Karupelv Valley $(2006 ; n=2)$ and Zackenberg Valley (2007; $n=1$, and 2008; $n=3$ ) were typed as Taenia crassiceps. Members of Taeniidae have previously been reported in Arctic foxes in many parts of the Arctic (Šiljaeva 1968; Kapel \& Nansen 1996; Stien et al. 2010; Meijer et al. 2011; Elmore et al. 2013), and possible intermediate hosts reside in north-east Greenland, including

Table 1. Faecal occurrence \% (95\% confidence interval) of endoparasitic helminthic eggs and larval stages (only for Strongyloides-like larvae) present in 275 faecal samples from Arctic foxes (Vulpes lagopus) collected at two localities in northeast Greenland during two-three consecutive years.

\begin{tabular}{|c|c|c|c|c|c|}
\hline \multirow[b]{2}{*}{ Species } & \multicolumn{3}{|c|}{ Zackenberg Valley } & \multicolumn{2}{|c|}{ Karupelv Valley } \\
\hline & $2006(n=95)$ & $2007(n=25)$ & $2008(n=104)$ & $2006(n=33)$ & $2007(n=18)$ \\
\hline \multicolumn{6}{|l|}{ Cestodea } \\
\hline Taeniidae $^{a}$ & $\begin{array}{c}0 \\
(0-3.81)\end{array}$ & $\begin{array}{c}12.0 \\
(2.6-31.2)\end{array}$ & $\begin{array}{c}13.5 \\
(7.6-21.6)\end{array}$ & $\begin{array}{c}9.1 \\
(1.9-24.3)\end{array}$ & $\begin{array}{c}0 \\
(0-18.5)\end{array}$ \\
\hline \multicolumn{6}{|l|}{ Nematoda } \\
\hline Toxascaris leonina & $\begin{array}{c}24.2 \\
(16.0-34.1)\end{array}$ & $\begin{array}{c}56.0 \\
(34.9-75.6)\end{array}$ & $\begin{array}{c}56.7 \\
(46.7-66.4)\end{array}$ & $\begin{array}{c}42.42 \\
(25.5-60.8)\end{array}$ & $\begin{array}{c}27.8 \\
(9.7-53.5)\end{array}$ \\
\hline Other Ascarididae & $\begin{array}{c}4.2 \\
(1.2-10.4)\end{array}$ & $\begin{array}{c}4.0 \\
(0.1-20.4)\end{array}$ & $\begin{array}{c}3.9 \\
(1.1-9.6)\end{array}$ & $\begin{array}{c}12.1 \\
(3.4-28.2)\end{array}$ & $\begin{array}{c}5.6 \\
(0.1-27.3)\end{array}$ \\
\hline Eucoleus boehmi & $\begin{array}{c}0 \\
(0-3.8)\end{array}$ & $\begin{array}{c}0 \\
(0-13.7)\end{array}$ & $\begin{array}{c}0 \\
(0-3.5)\end{array}$ & $\begin{array}{c}3.0 \\
(0.1-15.8)\end{array}$ & $\begin{array}{c}0 \\
(0-18.5)\end{array}$ \\
\hline Physalopteridae & $\begin{array}{c}3.2 \\
(0.7-9.0)\end{array}$ & $\begin{array}{c}0 \\
(0-13.7)\end{array}$ & $\begin{array}{c}0 \\
(0-3.5)\end{array}$ & $\begin{array}{c}3.0 \\
(0.1-15.8)\end{array}$ & $\begin{array}{c}0 \\
(0-18.5)\end{array}$ \\
\hline Ancylostomatidae & $\begin{array}{c}0 \\
(0-3.8)\end{array}$ & $\begin{array}{c}4.0 \\
(0.1-20.4)\end{array}$ & $\begin{array}{c}2.9 \\
(0.6-8.2)\end{array}$ & $\begin{array}{c}0 \\
(0-10.6)\end{array}$ & $\begin{array}{c}0 \\
(0-18.5)\end{array}$ \\
\hline Strongyloides-like larvae & $\begin{array}{c}2.1 \\
(0.3-7.40)\end{array}$ & $\begin{array}{c}0 \\
(0-13.7)\end{array}$ & $\begin{array}{c}0 \\
(0-3.5)\end{array}$ & $\begin{array}{c}0 \\
(0-10.6)\end{array}$ & $\begin{array}{c}0 \\
(0-18.5)\end{array}$ \\
\hline
\end{tabular}

${ }^{\mathrm{a}}$ In some of the samples, molecular typing of taeniid eggs revealed presence of Taenia crassiceps or $T$. serialis. 
rodents, lagomorphs and ungulates (Dalerum \& Angerbjörn 2000; Schmidt et al. 2008; Deplazes et al. 2013). The collared lemming and the Arctic hare (Lepus arcticus) could function as intermediate hosts for $T$. serialis and $T$. crassiceps, respectively (Deplazes et al. 2013). In Svalbard, a positive association between the abundance and distribution of intermediate hosts (reindeer or rodents) and the presence of taeniids, including T. crassiceps, in the Arctic fox has been found (Stien et al. 2010). On the other hand, the collapse of lemming cycles recently observed in east Greenland (Gilg et al. 2009; Schmidt et al. 2012) may have reduced the transmission of certain rodentdependent parasites, such as $T$. crassiceps, locally. Alternatively, preying on Arctic hares or scavenging on carcasses of the muskox (Ovibus moschatus) in the study areas (Schmidt et al. 2008) may allow for the transmission of other Taenia species.

Toxascaris leonina was the most prevalent endoparasite in Arctic foxes in studies based on adult worm isolation (e.g., Šiljaeva 1968; Rausch et al. 1990; Kapel \& Nansen 1996) and in coprological studies (Aguirre et al. 2000; Meijer et al. 2011; Elmore et al. 2013). The different egg stages of $T$. leonina detected in the present study could be indicative of egg development occurring outside the host, which is consistent with earlier observations of egg development at temperatures ranging from 6 to $37^{\circ} \mathrm{C}$ (Okoshi \& Usui 1968). Eggs in the category 'Other Ascarididae' (Table 1) could not be identified to species level because of their atypical morphology in egg size and shape.

Infections with Eucoleus boehmi (syn. Capillaria boehmi/Thomynx böhmi) have been reported in domestic and wild canids in Europe, North and South America (Davidson et al. 2006; Zajac et al. 2012), but to our knowledge not in Arctic foxes. Presumably, earlier post mortem and/or coprological studies on Arctic fox parasites (Aguirre et al. 2000; Meijer et al. 2011; Elmore et al. 2013) did not examine the nasal cavity (the preferred site of the adult worm), or did not observe the differences in egg morphology between species of Capillaria.

Four samples from our study contained eggs of Physalopteridae, which is a rare parasite in Arctic foxes based on previous post mortem investigations (Gubanov 1964; Rausch et al. 1990). As these eggs are heavy, sedimentation techniques are recommended for sensitive detection (Zajac et al. 2012). However, because of limited sample size such techniques could not be applied here.

Strongyloides stercoralis has previously been reported in Arctic foxes from Greenland and autoinfection has been suggested as a route of transmission (Kapel \& Nansen 1996). However, in the present study we detected Strongyloides-like larvae that had variable size range, which may either be caused by larval development in faecal samples outside the host or contamination of the samples by free-living larvae.

The hookworm (Ancylostomatidae) eggs currently found probably belonged to the genus Uncinaria, previously reported in Arctic foxes (Rausch et al. 1983) and known for its tolerance of low temperatures, unlike Ancylostoma caninum (Deplazes et al. 2013).

Although parasitological studies of foxes in Zackenberg Valley and Karupelv Valley have not been conducted before, previous studies from the circumpolar region (including nearby sites in east Greenland) have demonstrated a broad range of endoparasites, including acanthocephalans, trematodes, cestodes, nematodes and protozoans (Šiljaeva 1968; Rausch et al. 1983, 1990; Skírnisson et al. 1993; Kapel \& Nansen 1996; Aguirre et al. 2000; Elmore et al. 2013). The narrower range of parasites in the study reported here can be attributed to the applied coprological methodology and long-term storage of the samples. On the other hand, an advantage of coprology is that it can be used in future studies from the same site, where protection of the fox population does not allow for post mortem studies.

In conclusion, this study provides baseline data on Arctic fox parasitology from two study sites in northeast Greenland, which may form the basis for further studies of the effect of climate change on parasite transmission.

\section{Disclosure statement}

No potential conflict of interest was reported by the authors.

\section{ORCID}

Niels Martin Schmidt (D) http://orcid.org/0000-0002-41666218

Christian Moliin Outzen Kapel (D) http://orcid.org/00000002-9539-457X

Olivier Gilg (D) http://orcid.org/0000-0002-9083-4492

Mohammad Nafi Solaiman Al-Sabi (D) http://orcid.org/ 0000-0003-2277-4587

\section{References}

Aguirre A.A., Angerbjörn A., Tannerfeldt M. \& Mörner T. 2000. Health evaluation of Arctic fox (Alopex lagopus) cubs in Sweden. Journal of Zoo and Wildlife Medicine 31, 36-40.

Al-Sabi M.N.S., Deplazes P., Webster P., Willesen J.L., Davidson R.K. \& Kapel C.M.O. 2010. PCR detection of 
Angiostrongylus vasorum in fecal samples of dogs and foxes. Parasitology Research 107, 135-140.

Dalerum F. \& Angerbjörn A. 2000. Arctic fox (Alopex lagopus) diet in Karupelv Valley, east Greenland, during a summer with low lemming density. Arctic 53, 1-8.

Davidson R., Simard M., Kutz S.J., Kapel C.M.O., Hamnes I.S. \& Robertson L.J. 2011. Arctic parasitology: why should we care? Trends in Parasitology 27, 239-245.

Davidson R.K., Gjerde B., Vikøren T., Lillehaug A. \& Handeland K. 2006. Prevalence of Trichinella larvae and extra-intestinal nematodes in Norwegian red foxes (Vulpes vulpes). Veterinary Parasitology 136, 307-316.

Deplazes P., Eckert J., von Samson-Himmelstjerna G. \& Zahner H. (eds.) 2013. Lehrbuch der Parasitologie für die Tiermedizin. (Textbook of parasitology for animal medicine.) Stuttgart: Enke Verlag.

Ehrich D., Ims R.A., Yoccoz N.G., Lecomte N., Killengreen S.T., Fuglei E., Rodnikova A.Y., Ebbinge B.S., Menyushina I.E., Nolet B.A., Pokrovsky I.G., Popov I. Y., Schmidt N.M., Sokolov A.A., Sokolova N.A. \& Sokolov V.A. 2015. What can stable isotope analysis of top predator tissues contribute to monitoring of tundra ecosystems? Ecosystems 18, 404-416.

Elmore S.A., Lalonde L.F., Samelius G., Alisauskas R.T., Gajadhar A.A. \& Jenkins E.J. 2013. Endoparasites in the feces of Arctic foxes in a terrestrial ecosystem in Canada. International Journal for Parasitology: Parasites and Wildlife 2, 90-96.

Gilg O., Hanski I. \& Sittler B. 2003. Cyclic dynamics in a simple vertebrate predator-prey community. Science 302, 866-868.

Gilg O., Kovacs K.M., Aars J., Fort J., Gauthier G., Grémillet D., Ims R.A., Meltofte H., Moreau J., Post E., Schmidt N.M., Yannic G. \& Bollache L. 2012. Climate change and the ecology and evolution of Arctic vertebrates. Annals of the New York Academy of Sciences 1249, 166-190.

Gilg O., Sittler B. \& Hanski I. 2009. Climate change and cyclic predator-prey population dynamics in the High Arctic. Global Change Biology 15, 2634-2652.

Gilg O., Sittler B., Sabard B., Hurstel A., Sané R., Delattre P. \& Hanski I. 2006. Functional and numerical responses of four lemming predators in High Arctic Greenland. Oikos 113, 193-216.

Gubanov N.M. 1964. Gel'mintofauna promyslovyh mlekopitajuščih Jakutii. (Helminth fauna of economically important mammals of Yakutia.) Moscow: Nauka.

Hansen B.U., Sigsgaard C., Rasmussen L., Cappelen J., Hinkler J., Mernild S.H., Petersen D., Tamstorf M.P., Rasch M. \& Hasholt B. 2008. Present-day climate at Zackenberg. Advances in Ecological Research 40, 111149.

IUCN (International Union for Conservation of Nature). 2009. Species and climate change: more than just the polar bear. Cambridge: IUCN/Species Survival Commission.

Kapel C.M.O. \& Nansen P. 1996. Gastrointestinal helminths of Arctic foxes (Alopex lagopus) from different bioclimatological regions in Greenland. The Journal of Parasitology 82, 17-24.

Mathis A., Deplazes P. \& Eckert J. 1996. An improved test system for PCR-based specific detection of Echinococcus multilocularis eggs. Journal of Helminthology 70, 219222.

Meijer T., Mattsson R., Angerbjörn A., Osterman-Lind E., Fernández-Aguilar X. \& Gavier-Widén D. 2011. Endoparasites in the endangered Fennoscandian population of Arctic foxes (Vulpes lagopus). European Journal of Wildlife Research 57, 923-927.

Okoshi S. \& Usui M. 1968. Experimental studies on Toxascaris leonina. IV. Development of eggs of three ascarids, T. leonina, Toxocara canis and Toxocara cati, in dogs and cats. The Japanese Journal of Veterinary Science 30, 29-38.

Post E., Forchhammer M.C., Bret-Harte M.S., Callaghan T.V., Christensen T.R., Elberling B., Fox A.D., Gilg O., Hik D.S., Hoye T.T., Ims R.A., Jeppesen E., Klein D. R., Madsen J., McGuire A.D., Rysgaard S., Schindler D.E., Stirling I., Tamstorf M.P., Tyler N.J.C., van der Wal R., Welker J., Wookey P.A., Schmidt N.M. \& Aastrup P. 2009. Ecological dynamics across the Arctic associated with recent climate change. Science 325, 1355-1358.

Rausch R.L., Fay F.H. \& Williamson F.S.L. 1983. Helminths of the Arctic fox, Alopex lagopus (L.), in Greenland. Canadian Journal of Zoology 61, 1847-1851.

Rausch R.L., Fay F.H. \& Williamson F.S.L. 1990. The ecology of Echinococcus multilocularis (Cestoda: taeniidae) on St. Lawrence Island, Alaska. II. Helminth populations in the definitive host. Annales de Parasitologie Humaine et Comparee 65, 131-140.

Schmidt N.M., Berg T.B., Forchhammer M.C., Hendrichsen D.K., Kyhn L.A., Meltofte H. \& Hoye T. T. 2008. Vertebrate predator-prey interactions in a seasonal environment. Advances in Ecological Research 40, 345-370.

Schmidt N.M., Ims R.A., Hoye T.T., Gilg O., Hansen L.H., Hansen J., Lund M., Fuglei E., Forchhammer M.C. \& Sittler B. 2012. Response of an Arctic predator guild to collapsing lemming cycles. Proceedings of the Royal Society B: Biological Sciences 279, 4417-4422.

Schmidt N.M., Pedersen S.H., Mosbacher J.B. \& Hansen L. H. 2015. Long-term patterns of muskox (Ovibos moschatus) demographics in High Arctic Greenland. Polar Biology 38, 1667-1675.

Šiljaeva L.M. 1968. Gel'minty pesca i ih Vozdejstvie na populjaciju v Neneckom Nacional'nom Okruge. (Helminths in foxes and their impact on the host population in the Nenets Autonomous Okrug.) Zoologicheskii Zhurnal 3, 331-336.

Sittler B. 1995. Response of stoat (Mustela erminea) to a fluctuating lemming (Dicrostonyx groenlandicus) population in north east Greenland: preliminary results from a long term study. Annales Zoologici Fennici 32, 79-92.

Skírnisson K., Eydal M., Gunnarsson E. \& Hersteinsson P. 1993. Parasites of the Arctic fox (Alopex lagopus) in Iceland. Journal of Wildlife Diseases 29, 440-446.

Stien A., Voutilainen L., Haukisalmi V., Fuglei E., Mørk T., Yoccoz N.G., Ims R.A. \& Henttonen H. 2010. Intestinal parasites of the Arctic fox in relation to the abundance and distribution of intermediate hosts. Parasitology 137, 149-157.

Tamura K., Stecher G., Peterson D., Filipski A. \& Kumar S. 2013. MEGA6: molecular evolutionary genetics analysis version 6.0. Molecular Biology and Evolution 30, 2725 2729.

Trachsel D., Deplazes P. \& Mathis A. 2007. Identification of taeniid eggs in the faeces from carnivores based on multiplex PCR using targets in mitochondrial DNA. Parasitology 134, 911-920.

Zajac A.M., Conboy G.A., Greiner E.C., Smith S.A. \& Snowden K.F. 2012. Veterinary clinical parasitology. 8th edn. Chichester: Wiley-Blackwell. 